\title{
Effect of teacher mediation in play, mixed-sex play and gender-segregation in play on academic performance of low achieving pupils
}

\author{
Opeyemi Shoaga $^{1}$, Folorunso A. Ajasa $^{2}$ and Sesan O. Mabekoje ${ }^{1}$ \\ 1-Department of Educational Foundations and Counselling, Faculty of Education, Olabisi Onabanjo University, Ago Iwoye, Nigeria \\ 2-Department of Primary Education, School of Early Childhood Care and Primary Education, Emmanuel Alayande College of Primary Edu- \\ cation, Oyo, Nigeria \\ Corresponding author contact: mabekoje.sesan@oouagoiwoye.edu.ng
}

\begin{abstract}
This study investigated the effect of three play strategies on academic performance of low achieving Basic 1 pupils in primary schools in Oyo State, Nigeria. A quasi-experimental research design using pretest, posttest, control group was adopted where pupils screened to have low achievement scores were selected from schools randomly assigned to treatment groups. Participants met on different treatment strategies for eight weeks of two contact hours each. Academic performance was assessed before and after treatment with data analysed using Analysis of Covariance. Results indicated that the three play strategies are effective in improving pupils' academic performance ( $F_{(3124)}$ $=310.566 ; p<0.05)$. Based on the findings, it was recommended that any of the play strategies could be effectively utilized in improving the academic performance of low achieving pupils.
\end{abstract}

Keywords: Teacher mediation in play, Mixed-sex play, Gender-segregation in play, Academic performance

\section{Introduction}

Primary education is the basic and fundamental level in the Nigerian educational system. This is the framework on which the structure of the secondary and tertiary educational levels is built. A very strong foundation for the super structure has therefore been advocated. Despite the fact that learning is not limited to the cognitive aspect of education alone, academic performance of pupils is a major yardstick with which the achievement of educational goals is measured. Academic achievement of pupils at the primary educational level is therefore of importance. Efforts are therefore required to make certain that no pupil is left behind by ensuring that low achieving pupils are assisted to perform at maximal level. Play has been identified as a veritable tool in early childhood education (Shoaga, 2011). Play is an activity that is universally engaged in at the childhood stage and as a result cannot be overlooked (Barbu, Cabanes, \& Le Maner-Idrissi, 2011; Göncü \& Gaskins, 2007).

Research and recommendations from professional organisations like National Association for the Education of Young Children (NAEYC) and the National Association of Elementary School Principals (NAESP) revealed that with the help of playful learning, the child's confidence can be reinforced. Play is an active, adventurous and communicative way by which things are done but all the same enjoyable as play is exciting and full of fun. Play such as make-believe or role play, playing games with rules as well as engaging in resourceful outdoor play have all been identified to enhance knowledge, promote positive attitudes toward learning and schooling as well as improve skills. Play has also been identified to help children who have issues with self-regulation become improved and able to control their emotions, behaviour and ideas. The teachers' role in incorporating play activities that are well conformed to the educational standards set, help in promoting positive outcomes for the children. However, play serves as a pathway through which learning is achievable (NGA Center \& CCSSO, 2010).

It has been observed that children benefit from play therapy because it is developmentally appropriate (Stutey \& Wubbolding, 2018; Van Horne, Post, \& Phipps, 2018) and it allows children to speak in their native language of play (Stutey \& Wubbolding, 2018). Play therapies have been implemented on children with autism spectrum disorder (Guest \& Ohrt, 2018), trauma (Gonzalez \& Bell, 2016; Guest \& Ohrt, 2018; Olson-Morrison, 2017), maladaptive perfectionism and anxiety (Akay \& Bratton, 2017), high disruptive behaviour (Cochran \& Cochran, 2017; Ritzi, Ray, \& Schumann, 2017), Attention- 
Deficit/Hyperactivity Disorder (ADHD) (Robinson, Simpson, \&Hott, 2017), behavioural difficulties (Winburn, Gilstrap, \& Perryman, 2017) and externalizing behaviour and poor social skills (MeanyWalen \& Teeling, 2016).

Play therapies and strategies have been utilized to treat various psychological issues. For example, using play therapy in treating chronic illnesses in childhood has the potential to promote children's development, increase self-control, and enhance a healthy parent-child affiliation which serves as the bases for future health behaviours (Palmer, Pratt, \& Goodway, 2017).

Play and games are significant in promoting learning and fostering development (Pui-Wah, 2010; Pui-Wah \& Stimpson, 2004). The justification for advocating for play lies in its manifold educational benefits which include cognitive, emotional, physical and social advantages (Bergen, 2009; Meadows, 2014; Wood \& Attfield, 2005). In the same vein, play provides rewarding learning opportunities for children. Play affords adults to learn about children and their educational needs. Within the school context, it means that teachers are able to understand where children, locate where they are both in their learning and general development. This in turn provides educators with initial position for advancing new learning in both the affective and cognitive domains (Moyles, 2010).

Learning through playing can be observed from children's capacity to gain knowledge from using a diversity of approaches, such as conceptualizing, reasoning and problem solving (Bransford, Brown, \& Cocking, 2000). Play offers several potentials for the development of strategies, especially when children are encouraged to assume the position of expert. When assuming the role of expert, it is the belief of children that they are at liberty to operate in accordance to their desires and understanding and they are expected to thrive in their actions. Researchers (e.g. Hyvonen, 2011; Hyvonen \& Kangas, 2010) have noted that children appear to conceptually understand the essentials of suitable approaches. Children can generate and solve problems as they seek original challenges (Bransford et al., 2000); they expectedly do same so as to naturally advance learning in play (Hyvonen, 2008, Hyvonen \& Kangas, 2007, 2010).

Learning through play also lies in embodiment, where the entire body is involved in play as well as in learning processes. Embodiment is the process of combining a variety of physical actions with higher cognitive activities like perceiving, reasoning, reflecting and thinking (Price \& Rogers, 2004). Physicality is seen as being significant for children's wellbeing and academic attainment; for that reason, it is suggested that physical approaches to learning be made applicable across the curriculum (DuBose et al., 2008). Learning through play therefore, is not purely a cognitive but includes cultural, emotional, physical and social processes (Hyvonen, 2008).

Existing body of knowledge supports the various connections between play, learning and development. Nonetheless, researchers indicate the lack of play and playful techniques in schools and early childhood education (Bergen, 2009; Pui-Wah, 2010) especially when it is observed that there is a poor integration of play to the curriculum (Lord \& McFarland, 2010). With the insufficient integration, the act of learning has far been much more of the focal point than the purpose of learning thus emphasis has been on how children play rather than what they learn (Pramling-Samuelson \& Carlsson, 2008).

The quality of play has always been put to question by researchers (Bergen, 2002; Hujala, Helenius, \& Hyvonen, 2010) and the prospects for playful learning atmosphere that have been not been achieved (Maynard \& Waters, 2007; Price \& Rogers, 2004). Teachers' epistemologies of play constitute a major reason for both of these issues. Teachers mostly comprehend play and learning as dichotomous conceptions which are complicated to incorporate, either in practice or in thinking. Play therefore is often recognized more as a mechanical, teacher-led activity. Teachers require innovative understanding and insight for play and learning, since simply increasing possibilities for play in the classroom is not sufficient in enhancing play and learning (Pui-Wah \& Stimpson, 2004). New insight is required to relate teachers' pedagogical knowledge to play-based teaching, something which is currently limited. Teachers' pedagogical views about how they implement play are essentials as well (Hyvonen, 2011). If the function of play in elementary school is to be understood, one must comprehend and note how play activities are being organized, understanding of teachers' roles, when and how play should be organized as well as the groupings of sex of the participants should be of great concern to executors of play in any school setting.

It is well established that a positive teacher-pupil relationship in any school activity or programme is a developmental asset for children from pre-school to high school (Birch \& Ladd, 1997; Crosnoe, Johnson \& Elder, 2004; Hughes \& Kwok, 2006) pupils whose relationships with teacher are characterized 
by greater closeness, lower levels of aggression, truancy, less conflict and other behaviour problems (Birch \& Ladd, 1998; Hughes \& Kwok, 2006; Silver, Measelle, Armstrong, \& Essex, 2005). They also achieve at higher levels academically. More importantly, the quality of teacher-mediation or relationship in pupils' activities in the early grades has connotation for the future children's academic, behavioural, and social consequences (Hughes, Cavell \& Willson, 2001; Hughes \& Kwok, 2006; Ladd \& Burgess, 2001; Pianta \& Stuhlman, 2004).

The teacher stands as an affectionate and loving personality for little children, such that a safe, close and sound bond with the teacher (Hughes \& Kwok, 2006) especially during play or classroom learning activities enables children to cope better with social and academic challenges in pre-school and the early elementary grades (Hughes \& Kwok, 2006; van Ijzendoorn, Sagi, \& Lambermon, 1992). Thus a child's social interaction with teacher inside and outside the classrooms, academic motivation, and academic achievement constitute a shared and vibrant process by which early school experiences of children affect their long term social and academic adjustment (Hughes \& Kwok, 2006; Perry \& Weinstein, 1998).

Strong and stable evidences are lacking about the benefits of single-sex, or mixed-sex schooling. Nonetheless, a promising discovery is that the effects of single-sex or mixed-sex school on educational achievement cannot be appraised in a vacuum exclusive of the consideration of the socio-cultural context of the school. All the same, several promoters of co-educational schools are of the opinion that mixed-sex schools are indispensable to the extent that girls and boys can gain knowledge by living and working together. The common argument is that schools should reproduce life situations especially outof-school life. The society in the real sense of it is mixed; hence schools should also be co-educational (Smithers \& Robinson, 2006).

Little facts exist on the long term social outcomes of mixed-sex and single-sex education. Available evidence reveals that there are no steady dissimilarities in the development of boys and girls in bothmixed-sex and single-sex educational school types. There are convincing indications suggesting that there are no compelling distinction between students who attend co-educational compared to those who attend single-sex schools when ease of social adjustment to school life is considered (Bijlani \& Utreja, 2016; Datnow \& Hubbard, 2002).

Single-sex or single-gender or game-sex group is the same with gender-segregation (Kessels \& Hannover, 2008). Studies have reported that single-sex classrooms and schools are linked to less gender stereotyped academic attitudes (e.g. Kessels \& Hannover, 2008; Stables, 1990). For example, findings support that for self-concept of academic abilities, Mixed-Sex School (MSS) and Single-Sex School (SSS) although male students had more positive mathematics and science attitudes whereas female students had more positive attitudes about English. Single-sex school was linked to smaller gender gaps in these attitudes (Sullivan, 2009).Gender segregation is a pervasive but predominant same-sex grouping with readily obvious feature of children's playgroups (Serbin, Molla, Gulko, Powlishta, \& Colburne, 1994).

Two lines of analysis have been used by supporters of Single-Sex School (SSS) in supporting (SSS). The first is that male and female students have expressively diverse learning techniques which are grounded in the physiological and structural distinctions in the brains of boys and girls which require different learning environment (Else-Quest \& Peterca, 2015; James, 2009; Sax, 2006).

Evidence from neuroscience research concludes that there are few reliable differences between brains of boys and girls relevant to education and learning (Elliot, 2011). Likewise, it has been sustained that SSS reduces sexual disruption that arises from being in close proximity to or interrelating with members of the opposite gender (Else-Quest \&Peterca, 2015). There are arguments that teaching male and female students in a same-sex situation develops the self-concept of their capability in school subjects which are typically regarded as suitable for the other gender (Hoffman, Badgett, \& Parker, 2008; Norfleet \& Richards, 2003). In a way, educating male and female students in separate spaces may allow them to engage more liberally in subjects that are otherwise loaded with gender stereotypes (Else-Quest \& Peterca, 2015). Conversely, the abundance of SSS especially within the metropolitan schools has been part of the larger movement towards improving academic performance of low-income students (Goodkind, Shelbe, Joseph, Beers, \& Pinsky, 2013; Mitchell \& Stewart, 2003).

Variability in children's gender-typed activity preferences have been investigated across numerous preschool social contexts such as interactions with male peers, female peers, and both, solitary play, and interactions with teachers. Children's preferences for gender-typed activities differ by their own gender and the identity of the partners they interact with. Female and male children have preference for gender- 
typed activities with female children having preferences for feminine activities while in solitary play but activity preferences changed across social situations (Goble, Martin, Hanish, \& Fabes, 2012).

With the array of empirical evidences on the benefits of play on various aspects of development and learning, this study investigated the effect of teacher mediation in play, mixed-sex play and gendersegregation in play significantly affected the academic performance of low achieving pupils. It was hypothesized that there is no significant effect of teacher mediation in play, mixed-sex play and gendersegregation in play significantly affected the academic performance of low achieving pupils.

\section{Method}

\subsection{Design}

This study adopted a pre-test, post-test, control group, quasi experimental research design. Four treatment packages were employed in the study. These are:

(a) Teacher-mediation in play (TMP)

(b) Mixed-sex play (MSP)

(c) Gender-segregation in play (GSP)

(d) Conventional play style (method) (CPS)

\subsection{Sample and Sampling Technique}

There are thirty-three Local Government Areas in Oyo State. Four Local Governments Areas were selected using simple random sampling technique. In each of the four (4) local government areas selected, four (4) schools were selected using stratified random sampling technique, firstly along with the school location i.e. rural and urban; secondly along with the school type or ownership i.e. public and private. This list of schools according to school type and school location were collected from the local inspectors of education (LIE)'s office of each local government area. One school each was selected for urban-public, urban-private, rural-public and rural-private respectively. Therefore, papers were wrapped with inscription 'Yes or No' and pupils will be asked to pick one. 'Yes' will be selected while 'No' will not. This was done to ascertain that all pupils will be represented. Meanwhile, 20 pupils in each school were selected using stratified random sampling technique by sex which was 10 boys and 10 girls. This is because the population is heterogeneous. Therefore, the total number of 16 schools with 320 pupils was first sampled. The initial sample was administered with the Academic Performance Test to determine those who are achieving low academically. From the results of pupils' performance on the test, a median cut of 12 was used to determine the low achieving pupils. Hence, the 129 pupils who scored below the median score were screened to be low achieving and participated in the study

\subsection{Instrument}

\section{Academic Performance Test}

A 50-item multiple test in General Studies subject was developed by the researchers. The items covered the expected curriculum to be mastered in General Studies subject. A table of specification was drawn up for fifty (50) test items, while the cognitive domains measured were Knowledge and Comprehension, because of the pupils' level of assimilation. Kuder-Richardson 20 (KR-20) was applied to the scores in order to measure the internal consistency. This was done because it is being used to establish reliability coefficient of dichotomously scored items such as multiple-choice items. However, twentyfive (25) items were finally considered out of fifty (50) where the reliability coefficient level of 0.90 was obtained. The items with difficulty indices between 0.40 and 0.60 and with discriminating indices of $\geq 0.3$ were finally selected and used.

Meanwhile, both pre-test and post-test were administered on the respondents before and after the treatment. This was carried out to test the cognitive capability of the pupils on General Studies before and at the expiration of the treatment to determine play effects on pupils' academic performance. 
Table 1. Table of Specification

\begin{tabular}{|c|c|c|c|c|c|}
\hline $\mathrm{S} / \mathrm{N}$ & Contents in General Studies Subject Area & $\%$ & $\begin{array}{c}\text { Knowledge } \\
(60 \%)\end{array}$ & $\begin{array}{l}\text { Comprehension } \\
(40 \%)\end{array}$ & $\begin{array}{l}\text { Total } \\
100 \%\end{array}$ \\
\hline 1 & Personal hygiene/cleaning of the environment & $20 \%$ & 0605 & 0401 & 1006 \\
\hline 2 & Identification of colours & $20 \%$ & 0604 & $04 \mathbf{0 2}$ & 1006 \\
\hline 3 & Counting in child's language of immediate environment & $20 \%$ & $06 \mathbf{0 2}$ & 0401 & 1003 \\
\hline 4 & $\begin{array}{l}\text { Cultural heritage: dressing, language, occupation, and re- } \\
\text { spect, games, hairdo and music and dance }\end{array}$ & $20 \%$ & 0604 & $04 \mathbf{0 2}$ & 1006 \\
\hline 5 & Childs duties at home and school & $20 \%$ & $06 \mathbf{0 3}$ & $04 \mathbf{0 1}$ & 1004 \\
\hline & Total & & 3018 & 2007 & 5025 \\
\hline
\end{tabular}

The number of items by content and cognitive domain that were included in the final performance test are in bold fonts

\subsection{Procedure}

Study procedure followed three phases:

Phase One: This entails pre-treatment session. Researchers visited the schools selected for the study. The authority of each school was contacted before permission was obtained. Then, the researchers sought for the consent of the primary I teachers of all selected schools to serve as research assistants. Through the teachers in selected classes, a short note of permission letter was sent to the parents of the pupils. Researchers with other research assistants then agreed on the central venue used as a meeting place to discuss on their interactions with the pupils. There was briefing on the activities such as pretest and post-test administration, and treatment packages administered on the participants. During pretest session, participants were subjected to pre-test to determine their entry behaviour.

Phase Two: Treatments. This phase was devoted to the treatment proper and it lasted six weeks. Participants were exposed to treatment packages totalling six play activities for each treatment package. Then the control group was exposed to different play activities as determined by them. No placebo was rendered in this regard since they were familiar with the existing practices. Then, throughout each of the selected four schools in all four local government areas; similar treatments were given without distraction of any other different groups within the same school vicinity.

Phase Three: Post treatments. At the end of the intervention, post-test administration of the Achievement Test was conducted. Participants were debriefed, appreciated and commended.

\subsection{Method of Data Analysis}

Analysis of Covariance (ANCOVA) was used to analyse the data. Results were also tested at 0.05 level of significance.

\section{Results}

\subsection{Preliminary Analysis of Data}

Descriptive statistics of mean, standard error and confidence internal were determined as shown in Table 2 .

Table 2.Mean, Standard Error and Confidence Interval of Posttest Academic Performance Scores Grand Mean = 19.172

\begin{tabular}{|l|c|c|c|c|c|}
\hline & & & \multirow{2}{*}{} & \multicolumn{2}{|c|}{ 95\% Confidence Interval } \\
\cline { 5 - 7 } Treatment Group & $\mathrm{N}$ & Mean & Std. Error & Lower Bound & Upper Bound \\
\hline Teacher-mediation in play & 31 & $22.530^{\mathrm{a}}$ & 0.361 & 21.816 & 23.245 \\
\hline Mixed-sex play & 27 & $22.893^{\mathrm{a}}$ & 0.387 & 22.127 & 23.660 \\
\hline Gender-segregation in play & 42 & $21.827^{\mathrm{a}}$ & 0.311 & 21.211 & 22.443 \\
\hline Control & 29 & $9.438^{\mathrm{a}}$ & 0.373 & 8.700 & 10.176 \\
\hline
\end{tabular}

a. Pretest academic performance appearing as covariates in the model was evaluated at 9.8837 . 
The results in Table 2 showed that the three experimental groups had mean scores well above the grand mean of 19.172 as against the control group which had a mean score of 9.438 found to be lower than the grand mean score.

\subsection{Hypothesis Testing}

Table 3. Analysis of Covariance of Posttest Academic Performance

\begin{tabular}{|c|c|c|c|c|c|}
\hline Source & Type III Sum of Squares & df & Mean Square & F & Sig. \\
\hline Corrected Model & $3761.573^{\mathrm{a}}$ & 4 & 940.393 & 233.163 & 0.000 \\
\hline Intercept & 487.637 & 1 & 487.637 & 120.906 & 0.000 \\
\hline PreAch & 7.657 & 1 & 7.657 & 1.898 & 0.171 \\
\hline Treatment & 3757.728 & 3 & 1252.576 & 310.566 & 0.000 \\
\hline Error & 500.117 & 124 & 4.033 & & \\
\hline Total & 52983.000 & 129 & & & \\
\hline Corrected Total & 4261.690 & 128 & & & \\
\hline
\end{tabular}

a. $\mathrm{R}$ Squared $=.883$ (Adjusted R Squared $=.879$ )

Results in Table 3 showed that mean scores of participants were not significantly different at the pre treatment. However, significant differences existed at the post treatment assessment $\left(\mathrm{F}_{(3,124)}=310.566\right.$; $p<0.05)$. The hypothesis of no significant difference was rejected. In effect, teacher mediation in play, mixed-sex play and gender-segregation in play significantly affected the academic performance of low achieving pupils. To determine the direction of differences, the pairwise comparison was conducted as reported in Table 4.

Table 4. Pairwise Comparisons of Posttest Academic Performance

\begin{tabular}{|c|c|c|c|c|c|c|}
\hline \multirow[b]{2}{*}{ Treatment Group } & \multirow[b]{2}{*}{ Treatment Group } & \multirow[t]{2}{*}{ Mean Difference } & \multirow[t]{2}{*}{ Std. Error } & \multirow[t]{2}{*}{ Sig. ${ }^{b}$} & \multicolumn{2}{|c|}{$\begin{array}{l}95 \% \text { Confidence Interval for } \\
\text { Difference }^{\mathrm{b}}\end{array}$} \\
\hline & & & & & Lower Bound & Upper Bound \\
\hline \multirow[t]{3}{*}{ Teacher-mediation in play } & Mixed-sex play & -0.363 & 0.529 & 1.000 & -1.780 & 1.055 \\
\hline & Gender-segregation in play & 0.703 & 0.477 & 0.860 & -.577 & 1.984 \\
\hline & Control & $13.092^{*}$ & 0.519 & 0.000 & 11.701 & 14.483 \\
\hline \multirow[t]{3}{*}{ Mixed-sex play } & Teacher-mediation in play & 0.363 & 0.529 & 1.000 & -1.055 & 1.780 \\
\hline & Gender-segregation in play & 1.066 & 0.498 & 0.206 & -.270 & 2.402 \\
\hline & Control & $13.455^{*}$ & 0.537 & 0.000 & 12.014 & 14.896 \\
\hline \multirow[t]{3}{*}{ Gender-segregation in play } & Teacher-mediation in play & -0.703 & 0.477 & 0.860 & -1.984 & 0.577 \\
\hline & Mixed-sex play & -1.066 & 0.498 & 0.206 & -2.402 & 0.270 \\
\hline & Control & $12.389^{*}$ & 0.486 & 0.000 & 11.085 & 13.693 \\
\hline \multirow[t]{3}{*}{ Control } & Teacher-mediation in play & $-13.092^{*}$ & 0.519 & 0.000 & -14.483 & -11.701 \\
\hline & Mixed-sex play & $-13.455^{*}$ & 0.537 & 0.000 & -14.896 & -12.014 \\
\hline & Gender-segregation in play & $-12.389^{*}$ & 0.486 & 0.000 & -13.693 & -11.085 \\
\hline
\end{tabular}

Based on estimated marginal means

*. The mean difference is significant at the 0.05 level.

b. Adjustment for multiple comparisons: Bonferroni.

The results in Table 4 revealed that each of the play strategies had significant effect on academic performance of low achieving pupils, over and above the control group. Pupils in the mixed play group had higher performance than those in the teacher mediation in play and gender-segregation in play in that order. This result is graphically presented in Figure 1. Descriptive statistics of data showing mean scores of treatment groups are as presented in Table 2. 


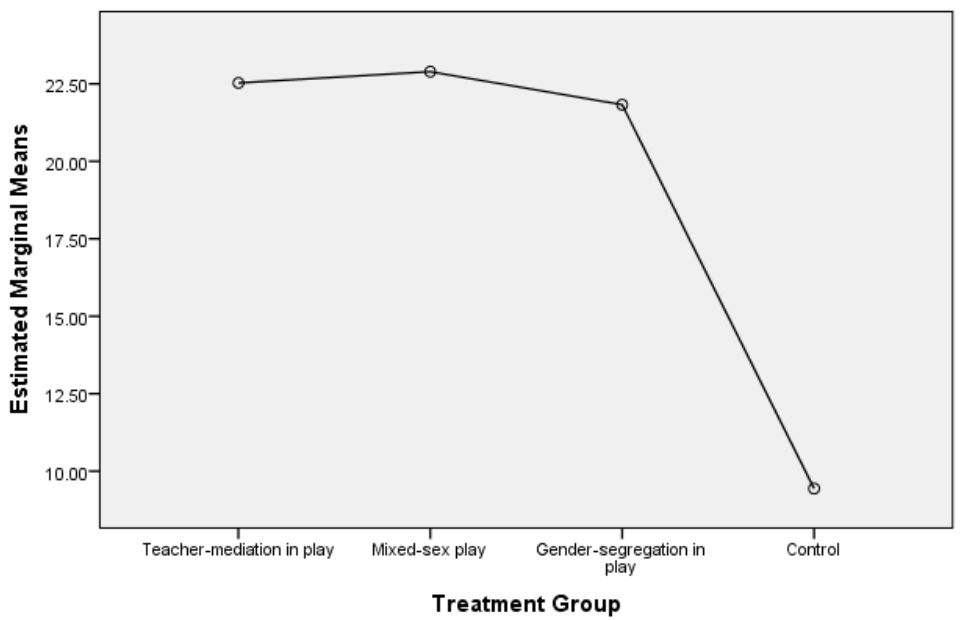

Fig. 1. Chart of the Treatment Effect on Pupils' Academic Performance

Note: Pretest Academic performance appearing covariates in the model was evaluated at 9.8837.

\section{Discussion}

This study investigated the effect of teacher mediation in play, mixed-sex play and gender-segregation in play significantly affected the academic performance of low achieving pupils. Results indicated that the three play strategies are effective and provided gains significantly over that of the conventional method of teaching the pupils. This led to the rejection of the hypothesis that there is a significant effect of teacher mediation in play, mixed-sex play and gender-segregation in play significantly affected the academic performance of low achieving pupils.

It is not surprising that findings of this study revealed significant effect of the three play strategies on pupils' academic performance. In fact, it would have been amazing if the strategies were not effective. First, play has been recommended in the Nigeria National Policy on Education (FGN, 2013) as a means of instruction for children in early childhood.

Play therapies have also been noted to be used because of the perceived effectiveness, given the fact that play therapy is the most developmentally appropriate approach to elementary school-age children (Van Horne et al.,2018).This indicated that the application of the treatments was so significant on the academic performance of the participants. It could be deduced from the finding that play significantly contributes to pupils' academic performances. Therefore, teacher-mediation in play mixed-sex play and gender-segregation in play should be applied or adopted as instruments of improving primary school pupils' academic performance. Therefore, the mean score ranging from the highest which was teachermediation, followed by mixed-sex play group and lastly gender-segregation play group was so closed but very wide from the control group. This result was in line with the work of (Lau, Higgins, Geifer, Hong, \& Miller, 2005) that teacher-mediation has been associated with positive social interaction that could arouse pupils' positive attitude to learning and schooling and finally improving their academic performance if carefully introduced into pupils' play activities in a school setting. It has been reiterated that mixed-sex group play can provide a safe place for learning about similarities and differences across gender and for the development of skills (Hanish \& Fabes, 2014; Mabagala, 2016). Meanwhile gendersegregation also plays important roles in pupils' academic performance which was in line with the idea of that both boys and girls have different experiences and learn skills, competencies and interest in their interactions with same-sex peers (Fabes, Martins, \& Hanish, 2003). However, this contradicts the idea that the boys tend to incur harsh criticism when they cross gender lines to play with girls (Cook \& Cook, 2009).

\section{Conclusion}

It was concluded that teacher mediation in play, mixed-sex play and gender-segregation in play are effective play strategies for enhancing the academic performance of low achieving pupils in primary 
schools. It was also concluded that while the three strategies are effective and could be used in improving the academic performance of pupils, the mixed-sex play strategy was more effective than either of teacher mediation in play and gender-segregation in play strategies.

\section{Recommendations}

By the findings and conclusion of this study, mixed-sex play, teacher mediation in play, and gendersegregation are good play strategies. The play strategies could be varied since it has been established that inconsistency are observed in children's gender-typed activity inclinations. It is therefore recommended that for the improvement in academic performance of low achieving pupils, any of the play strategies could be applied.

Further studies could be conducted on play strategies as implemented by public and private schools to determine if there are differences in the structure and style of play strategies as they affect academic performance of low achieving pupils.

\section{References}

Akay, S., \& Bratton, S. (2017). The effects of Adlerian play therapy on maladaptive perfectionism and anxiety in children: A single case design. International Journal of Play Therapy, 26(2), 96-110. https://doi.org/10.1037/pla0000043

Barbu, S., Cabanes, G., \& Le Maner-Idrissi, G. (2011). Boys and girls on the playground: sex differences in social development are not stable across early childhood. PLoS One, 6(1), e16407. https://doi.org/10.1371/journal.pone.0016407

Bergen, D. (2002). The role of pretend play in children's cognitive development. Early Childhood. Research and Practice, 4(1). Retrieved June 6, 2010, from http://ecrp.uiuc.edu/v4n1/bergen.html

Bergen, D. (2009). Play as the learning medium for future scientists, mathematicians and engineers. American Journal of Play Spring, 1 (4), 413-428.

Bijlani, D. \&Utreja, D. (2016). Comparative analysis of feminism-related ideologies among students in single-sex and coeducational institutions. SSRN Electronic Journal. https://doi.org/10.2139/ssrn.2781398

Birch, S. H., \& Ladd, G. W. (1997). The teacher-child relationship and children's early school adjustment. Journal of School Psychology, 35, 61-79

Birch, S. H., \& Ladd, G. W. (1998). Children's interpersonal behaviors and the teacher-child relationship. Developmental Psychology. 34,934-946

Brandsford, J. D., Brown, A. L., \& Cocking, R. R. (2000). How people learn: Brain mind and school. Washington: National Academy Press.

Cochran, J. L.; Cochran, N. H. (2017). Effects of child-centered play therapy for students with highlydisruptivebehavior in high-poverty schools. International Journal of Play Therapy, 26(2), 5972. https://doi.org/10.1037/pla0000052

Cook, J. L. \& Cook, G. (2009). Gender segregation among childhood friends. Excerpt from child development principles and Perspectives. (pp. 423-425)

Crosnoe, R., Johnson, M. K., \& Elder, G. H. (2004). International bonding in school: The behavioural and contextual correlates of student-teacher relationships. Sociology of Education, 77, 60-81. 
Datnow, A. \& Hubbard, L. (2002). Gender in policy and practice: Perspectives on single-sex and coeducational schooling. New York and London: Routledge Falmer, Taylor \& Francis Group.

DuBose, K. D., Mayo, M. S., Gibson, C. A., Greed, J. L., Hill, J. O., \& Jacobson, D. J. (2008). Physical Activity Across Curriculum (PAAC): Rationale and Design, Contemporary Clinical Trails, 29, 83-93.

Elliot, L. (2011). Single-sex education and the brain. Sex Roles, 69, 363-381.

Else-Quest, N. M. \&Peterca, O. (2015). Academic Attitudes and Achievement in Students of Urban Public Single-Sex and Mixed-Sex High Schools. American Educational Research Journal 52(4), 693-718. https://doi.org/10.3102/0002831215591660

Fabes, R. A., Martin, C. L. \&Hanish, L. D. (2003). Young children's play qualities in same-other-and mixed-sex peer groups. Child Development,74, 921-932.

Federal Republic of Nigeria (2013). National Policy on Education. Lagos Nigeria, NERDC.

Goble, P., Martin, C. L., Hanish, L. D. \&Fabes, R. A. (2012). Children's gender-typed activity choices across preschool social contexts. Sex Roles, 67, 35-451. https://doi.org/10.1007/s11199-012$0176-9$

Göncü, A., \& Gaskins, S. (2007). Play and development: Evolutionary, sociocultural, and functional perspectives. (p.328) NJ: Lawrence Erlbaum.

Gonzalez, C. L., Bell, H. (2016). Child-centered play therapy for Hispanic children with traumatic grief: Cultural implications for treatment outcomes. International Journal of Play Therapy, 25(3), 146-153. https://doi.org/10.1037/pla0000023

Goodkind, S., Schelbe, L., Joseph, A. A., Beers, D. E., \& Pinsky, S. L. (2013). Providing new opportunities or reinforcing old stereotypes? Perceptions and experiences of single-sex public education. Children and Youth Services Review, 35, 1174-1181.

Guest, J. D., \&Ohrt, J. H. (2018). Utilizing child-centered play therapy with children diagnosed with autism spectrum disorder and endured trauma: A case example. International Journal of Play Therapy, 27(3), 157-165. https://doi.org/10.1037/pla0000074

Hanish, L. D.,\&Fabes, R.A. (2014). Peer socialization of gender in young boys and girls. Retrieved on 6th March 2019 from http://www.child-encyclopedia.com/sites/default/files/textes-experts/en/2492/peer-socialization-of-gender-in-young-boys-and-girls.pdf

Hoffman, B. H., Badgett, B. A., \& Parker, R. P. (2008). The effect of single-sex instruction in a large, urban, at risk high school. The Journal of Educational Research, 102, 15-35.

Hughes, J. N., \& Kwok, O. (2006). Classroom engagement mediates the effect of teacher-student support on elementary students' peer acceptance: A prospective analysis. Journal of School Psychology, 43(6), 465-480. https://doi.org/10.1016/j.jsp.2005.10.001

Hughes, J. N., Cavell, T. A. \&Willson, V. (2001). Further support for the developmental significance of the quality of the teacher-student relationship. Journal of School Psychology.39, 289-301.

Hujala, E., Helenius, A. \&Hyvonen, P. (2010). Play for learning and transition to school. In M. Ebbeck\& M. Waniganayake (Eds.), Children's play in early childhood education: Facilitating learning in diversecontexts (pp. 89-102). Australian: Oxford University Press. 
Hyvonen, P. \& Kangas, M. (2010). Children as experts in designing play environment. In E.L. Kronqvist\& P. Hyronen (Eds.). Insights and Outlouds: Childhood research in the North, 143170. Acta Universitatis Ouluensis E 107, Oulu: Oulu University Press.

Hyvonen, P. (2008). Affordances of playful learning environment for tutoring playing and learning. Doctoral dissertation, Acta Universitatis Lappoensis. 152 University of Lapland, Faculty of Education, Finland, Rovaniemi: University of Lapland Printing Centre.

Hyvonen, P. (2011). Play in the School Context? The Perspectives of Finnish Teachers. Australian Journal of Teacher Education, 36(8), 65-83

Hyvonen, P., \& Kangas, M. (2007). From Bogey mountains to funny houses: Children's desires for play environment, Australian Journal of Early Childhood (AJEC); 32(3), 39-47.

James, A. N. (2009). Teaching the female brain: How girls learn mathematics and science. Thousand Oaks, C.A: Corwin Press.

Kessels, U. \& Hannover, B. (2008). When being a girl matters less: Accessibility of gender-related selfknowledge in single-sex and coeducational classes and its impact on students' physics-related self concept of ability. British Journal of Educational Psychology,78, 273-289.

Ladd, G. W., \& Burgess, K. B. (2001). Do relational risks and protective factors moderate the linkages between childhood aggression and early psychological and school adjustment? Child Development.72, 1579-1601.

Lau, C., Higgins, K., Geifer, J., Hong, E. \& Muller (2005). The effects of teacher-mediation of the social interactions of young children during computer activities topics in Early Childhood. Special Education.25(4), 208-217.

Lord, A.,\& McFarland, L. (2010). Pre-service primary teachers' perceptions of early childhoodphilosophy and pedagogy: A case study examination. Australian Journal of TeacherEducation, 35(3), $1-113$.

Mabagala, S. (2016). Primary school children's gender differences in playful activities. The Swedish Journal of Scientific Research, 3(4), 10-15

Maynard, T. \& Waters, J. (2007). Learning in the outdoor environment: A missed opportunity. Early Years, 27 (3), 255-265.

Meadows, V. (2014). Understanding child development. London: Routledge

Meany-Walen, K. K., \&Teeling, S. (2016). Adlerian play therapy with students with externalizing behaviors and poor social skills. International Journal of Play Therapy, 25(2), 64-77. https://doi.org/10.1037/pla0000022

Mitchell, A. B., \& Stewart, J. B. (2013). The efficacy of all-male academics: Insights from critical race theory (CRT). Sex Roles, 69, 382-392.

Moyles, J. (2010). The Excellence of Play. $3^{\text {rd }}$ edition. Berkshire: Open University Press. p. 4

National Governors Association Centre \& Council of Chief State School Officers (2010). Why Play is a Pathway to Learning: "Common Core State Standards for English Language Arts and Literacy in History/Social Studies, Science and Technical Subjects”. Retrieved on 16 Jan, 2019 from www.corestandards.org/wp-content/uploads/ELA-standards.pdf. 
Norfleet, J. A., \& Richards, H. C. (2003). Escaping stereotyping: Educational attitudes of male alumni of single-sex and coed schools. Psychology of Men and Masculinity, 4, 136-148.

Olson-Morrison, D. (2017). Integrative play therapy with adults with complex trauma: A developmentally-informed approach. International Journal of Play Therapy, 26(3), 172-183. https://doi.org/10.1037/pla0000036

Palmer, E. N., Pratt, K. J., \& Goodway, J. (2017). A review of play therapy interventions for chronic illness: Applications to childhood obesity prevention and treatment. International Journal of Play Therapy, 26(3), 125-137. https://doi.org/10.1037/pla0000045

Perry, K. E., \& Weinstein, R. S. (1998). The social context of early schooling and children's school adjustment. Educational Psychologist. 33, 77-194.

Pianta, R. C. \&Stuhlman, M. W. (2004). Conceptualizing risk in relational term: Associations among the quality of child-adult relationships prior to school entry and children's developmental outcomes in first grade. Educational and Child Psychology Special Issue: At Risk Children from Birth to Elementary School Age: Research Findings and Reflections on Intervention from an International Perspective.21 (1), 32-45.

Pramling-Samuelsson, I. \&Asplund, M. C. (2008). The playing learning child: Towards a pedagogy of early childhood. Scandinavian Journal of Educational Research, 52(6), 623-641.

Price, S., \& Rogers, Y. (2004). Let's get physical: The learning benefits of interacting in digitally argumented physical spaces. Computer and Education, 43 (1 \& 2), 137-151.

Pui-Wah, D. (2010). Exploring the tactfulness of implementing play in the classroom: A Hong-Kong experience. Asia Pacific Journal of Teacher Education, 38(1), 69-82.

Pui-Wah, D. C., \& Stimpson, P. (2004). Articulating contrasts in kindergarten teachers' implicit knowledge on play-based learning. International Journal of Educational Research, 41, 339352.

Ritzi, R. M., Ray, D. C., \& Schumann, B. R. (2017). Intensive short-term child-centered play therapy and externalizing behaviors in children. International Journal of Play Therapy, 26(1), 33-46. https://doi.org/10.1037/pla0000035

Robinson, A., Simpson, C., \&Hott, B. L. (2017). The effects of child-centered play therapy on the behavioral performance of three first grade students with ADHD. International Journal of Play Therapy, 26(2), 73-83. https://doi.org/10.1037/pla0000047

Sax, L. (2006). Six degrees of separation: What teachers need to know about the emerging science of sex differences.Educational Horizons, 84, 190-212.

Serbin, L. A., Mollq, L. C., Gulko, J., Powlishta, K. K., \&Colburne, K.A. (1994). The emergence of gender segregation in toddler playgroups. New Directions for Child and Adolescent Development, 65, 7-17

Shoaga, O. O. (2011). A philosophical examination of the relevance of play in fostering learning in early childhood education in Nigeria. Unpublished Ph.D thesis, University of Ibadan, Ibadan.

Silver, R. B., Measelle, J. R., Armstrong, J. M. \& Essex, M. J. (2005). Trajectories of classroom externalizing behaviour: Contributions of child characteristic, family characteristics, and the teacherchild relationship during school transition. Journal of School Psychology.43, 39-60. 
Smithers, A. \& Robinson, P. (2006).The paradox of single-sex and co-educational schooling. Buckingham: Carmichael Press.

Stables, A. (1990). Differences between pupils from mixed and single-sex schools in their enjoyment of school subjects and in their attitudes to science and to school. Educational Review 42(3), 221230. https://doi.org/10.1080/0013191900420301

Stutey, D. M., \&Wubbolding, R. E. (2018). Reality play therapy: A case example. International Journal of Play Therapy, 27(1), 1-13. https://doi.org/10.1037/pla0000061

Sullivan, A. (2009). Academic self-concept, gender and single-sex schooling. British Educational Research Journal, 35, 259-288.

Van Horne, J. W., Post, P. B., \& Phipps, C. B. (2018). Factors related to the use of play therapy among elementary school counselors. International Journal of Play Therapy, 27(3), 125-133. https://doi.org/10.1037/pla0000073

Van Ijzendoorn, M. H., Sagi, A., \&Lambermon, M. W. E. (1992). The multiple caretaker paradox: Data from Holland and Israel. In: R. C. Pianta (Ed). Beyond the parent: The role of other adults in children's lives (pp. 5-24) San Francisco: Jossey-Bass Publishers.

Winburn, A., Gilstrap, D., \& Perryman, M. (2017). Treating the tiers: Play therapy responds to intervention in the schools. International Journal of Play Therapy, 26(1), 1-11. https://doi.org/10.1037/pla0000041

Wood, E. \& Artfield, J. (2005). Play, learning and early childhood curriculum ( ${ }^{\text {nd }}$ edition). London: Sage Publications. 